\title{
To Mull Remittance and Misery Index of Selected Asian Countries: A Panel ARDL Approach
}

\author{
MUHAMMAD IBRAHIM SAEED \\ Research Associate, Office of Research Innovation and Commercialization, \\ University of Management and Technology, Lahore, Pakistan. \\ Email: ibrahim.saeed@umt.edu.pk \\ Tel: +923340413900 \\ SIDRA RAZA \\ Editorial Assistant, Office of Research Innovation and Commercialization, \\ University of Management and Technology, Lahore, Pakistan. \\ Email: sidra.raza@umt.edu.pk \\ Tel: +923339805950
}

FARAN ALI

Academic officer, Department of Finance and Islamic Banking, University of Management and Technology, Lahore, Pakistan.

Email: faran.ali@umt.edu.pk

Tel: +9234587230

\begin{abstract}
The objective of the study is to empirically probe the impact of misery index on remittance. Six Asian countries have been selected for the period of 1980-2016. The study uses panel ARDL approach with Cointegration. The results of Kao test shows that remittances and misery index are co-integrated. Panel $A R D L$ results show that misery index has a positive and significant impact on remittances in the long run but it is negative and insignificant in the short run. The results underpin the altruism theory in remittance sending behavior in the selected Asian countries. Remittance and unstable macroeconomic condition are directly proportional to each other in Asian developing countries. The government may scrutinize and determine the threshold level of instability otherwise the inflow of remittance might decrease.
\end{abstract}

Keywords: Altruism, Ardl, Inflation, Misery Index, Remittance, Unemployment.

\section{Introduction}

The mounting popularity of the remittance comes from the realization of the important role these play in poverty alleviation, and broadly speaking, in economic development. Countries confront high inflation and unemployment are more vulnerable to remittance. More than forty decades ago Walsh (1974) highlighted that unemployment and inflation are the macroeconomic variables which compel skilled labor to move from developing countries to developed countries for better living standard and employment opportunities. 'Remittances are a lifeline for developing countries' the posit statement carry some weight for the countries having high debt, slow economic growth, current account deficit and fiscal deficit. Poor countries have witnessed yet again a rise in remittances by 4.8 percent World Bank (2017). 
Misery index was coined by Arthur Okun in 1970, which gauges country's economic activity. It is just the entirety of unemployment and inflation rate. The index reflects economic execution of an economy as well as uncovers an imperative economic measurement of the personal satisfaction. Our study underpins the theory of Altruism which is based on the behavior of one person to increase the welfare of another person. For example Adam Smith once said: "The members of his own family, those who normally live with him in the same home, his parents, his children, his brothers and sisters, are, of course, the objects of his warmest affections. Naturally and typically, they are the individuals whose happiness or suffering would have the greatest effect on their conduct. He has been more used to sympathising with them. He understands better how they are going to be affected by it, and his sympathy for them is more specific and determined than it might be for most other people. In brief, it comes closer to what he thinks about himself, (Smith, 1976)".

Retrospect, the association between remittance and inflation can be seen in many empirical studies. Weakening in the purchasing power of inhabitants because of an expansion in price levels pushes nonnatives to dispatch more cash keeping in mind the expectations for everyday comforts of their families back home (Awdeh, 2018). Heilmann (2006) argues that inflationary pressure can be created by remittance inflows, especially if they increase the internal demand for imported goods. In an arrangement of 54 developing nations for the period 1955-2004, Narayan et al (2011) affirm this effect, showing that remittance creates inflationary pressure, which is illustrated in the long term. The findings of Diego and Ruby (2014) also highlighted positive relationship between inflation and remittance. There are other factors which have positive relationship with inflation but the magnitude is small in contrast with remittances (Hai \& Doan, 2017).

The relationship between unemployment and remittances has also been scratched by many researchers. If unemployment increases and more people are out of jobs, that results in more dependency on remittances from relatives and friends and this situation will expand remittance (Campbell, 2003). Another study by Lin (2011) underpins Positive relationship between remittances and unemployment for the country Tonga. Broadly speaking, his results revel that macroeconomic indicators and fluctuation in the currency influence remittances. To be succinct, his findings depict that growth of remittances dwindles because of two reasons, first the appreciation in Tongan currency and the second is lower unemployment rate in remitting country.

The strands of literature focus the effects of inflation on remittance and unemployment on remittance separately but there are very few or might be one or two studies which have shown relationship between misery index (which is combination of both unemployment and inflation) and remittance. One trait of the study that makes it different from others is the combination of inflation and unemployment (misery index) for six South Asian countries. The relationship between misery index and remittance can be viewed in the work of (Akçay, 2018). His study examines the short and long run association between remittance and misery index in case of Turkey. The results of the study unveil that in the long run misery index has a positive and significant impact on remittance, the same impact can be observed in the short run. So the objective of the present study is to empirically investigate the impact of misery index on remittance in selected Asian countries. The rest of the paper is assembled as follows:

Section 2 consists of data, methodology and model of the study, Section 3 is reserved for the discussion of the empirical results. Lastly, section 4 presents conclusion and policy implications.

\section{Data, Methodology and Model}

\section{Data}

The study uses panel data from 1980-2016 for 6 Asian countries namely India, Pakistan, China, Malaysia, Sri Lanka and Thailand. The countries have been taken into account because of the immense growth in remittance. Pakistan, China and India are among the top 5 remittance receiving countries (World Bank, 
2016). The data has been collected from WDI (World Development Indicators), The World Bank, CIA World fact-book, Knoema, Key Statistics of Labor Force, World Data Atlas, FRED Economic data.

\section{Methodology}

The decision to use Panel ARDL is dependent on the outcome of panel unit root test. Panel ARDL results can be spurious if any of the variable under study is I(2). Kao Residual Cointegration Test is applied to check the long run association between the variables. Furthermore, in order to probe misery index with remittance, the study prefers the method of pooled mean group estimation (PMGE), (see for details, Pesaran et al., 1999). The time periods $\mathrm{t}=1,2 \ldots \mathrm{T}$, groups $\mathrm{i}=1,2 \ldots \mathrm{N}$ and $\mathrm{y}$ is the dependent variable:

$$
y_{i t}=\sum_{j=1}^{p} \lambda_{i j} y_{i, t-j}+\sum_{j=0}^{q} \gamma_{i j} x_{i, t-j}+\mu_{i}+\varepsilon_{i t}
$$

Where $y_{i t}$ represents scalar dependent variable, $x_{i t}$ shows $\mathrm{k} \times 1$ vector of independent variables for group $i$, $\mu_{i}$ shows the fixed effects, $\lambda_{i j}$ 's stand for scalar coefficients of the lagged dependent variables, $\gamma_{i j}$ 's are $\mathrm{k}$ $\times 1$ coefficient vectors.

The re-parameterised method of Equation (2) is written as:

$$
\Delta y_{i t}=\emptyset_{i} y_{i, t-1}+\beta_{i} x_{i, t-1}+\sum_{j=1}^{p-1} \lambda_{i j} \Delta y_{i, t-j}+\sum_{j=0}^{q-1} \gamma_{i j} \Delta x_{i, t-j}+\mu_{i}+\varepsilon_{i t}
$$

\section{The Model}

The model in this study has been developed considering best possible combination of the control variables that might effect remittances.

\section{Stochastic form of the Model}

$$
L R E M_{i t}=\alpha_{i}+\beta_{1} M I_{i t}+\beta_{2} P O P_{i t}+\beta_{3} A D R_{i t}+\beta_{4} G D P_{i t}+\varepsilon_{i t}
$$

\section{Results and Discussion}

Table I: Descriptive Statistics

\begin{tabular}{|c|c|c|c|c|c|}
\hline & LREM & MI & PG & GDP & ADR \\
\hline Mean & 0.069078 & 0.102418 & 1.609541 & 6.176718 & 59.59910 \\
\hline Median & 0.144307 & 0.086433 & 1.600242 & 5.948716 & 58.42158 \\
\hline Maximum & 1.010624 & 0.594844 & 3.360418 & 15.13917 & 88.87107 \\
\hline Minimum & -1.698970 & -0.007050 & 0.299466 & -7.633734 & 35.59040 \\
\hline Std. Dev. & 0.666051 & 0.070542 & 0.769245 & 3.295425 & 14.25731 \\
\hline Skewness & -0.657336 & 2.631365 & 0.241940 & -0.485150 & 0.317568 \\
\hline Kurtosis & 2.773623 & 15.03008 & 2.226029 & 5.300799 & 2.297443 \\
\hline Observations & 222 & 222 & 222 & 222 & 222 \\
\hline
\end{tabular}

The result of the descriptive statistics in Table I shows significant variation in the data. Personal remittance has a smallest value of -1.69 while its extreme value is 1.01 , smallest value of misery index is --0.007050 meanwhile the extreme value is 0.594844 showing the highest variation, smallest value of gross domestic product is -7.633734 meanwhile extreme value is 15.13 , smallest value of population growth is 0.299 while the extreme value is 3.36 which shows lowest variation, smallest value of age dependency ratio is 35.5 meanwhile extreme value is 88.87 . We can interpret from the above table there is no significant divergence in the data indicating no signs of outliers. The skewness value remittance, population growth, gross 
domestic product and age deepens ratio shows normal distribution. For the kurtosis to be normal the value should be near to 3 as in the case of age dependency ratio, population growth and remittances.

Table II: Panel Unit Root Test

\begin{tabular}{|c|c|c|c|}
\hline \multicolumn{3}{|c|}{ LEVIN, LIN \& CHU } & Order of Integration \\
\hline Variable & Level & $1^{\text {st }}$ difference & $\mathrm{I}()$, \\
\hline LREM & 0.2937 & $0.0000^{* * *}$ & $\mathrm{I}(1)$ \\
\hline MI & $0.0000^{* * *}$ & - & $\mathrm{I}(0)$ \\
\hline PG & $0.0717^{*}$ & - & $\mathrm{I}(0)$ \\
\hline GDP & $0.0000^{* * *}$ & - & $\mathrm{I}(0)$ \\
\hline ADR & $0.0187^{* *}$ & - & $\mathrm{I}(0)$ \\
\hline
\end{tabular}

Table II depicts the result of panel unit root test. The results show that age dependency ratio, misery index population growth and gross domestic product accept the alternative hypothesis of no unit root while remittance does not accept the alternative hypothesis of unit root. To debar possibility of I (2) variable unit root test is applied in panel ARDL approach (Pesaran et al., 2001). In present study there is no order of integration I (2) so panel ARDL is appropriate for the estimation.

Table III: Kao Residual Cointegration Test

\begin{tabular}{|c|c|c|}
\hline \multicolumn{3}{|c|}{ Newey-West automatic bandwidth selection and Bartlett kernel } \\
\hline & t-Statistic & Prob. \\
\hline ADF & -3.149096 & 0.0008 \\
\hline Residual variance & 0.017394 & \\
\hline HAC variance & 0.016840 & \\
\hline
\end{tabular}

The result of Kao residual conintegration test is presented in Table III. The result of Kao test reject the null hypothesis (no cointegration) and alternative hypothesis has accepted because the probability value is less than 0.10 .

Table IV: Variance Inflation Matrix

\begin{tabular}{|c|c|c|c|c|c|}
\hline & LOGREM & MI & PG & GDP & ADR \\
\hline LOGREM & 1 & & & & \\
\hline MI & 1.154177 & 1 & & & \\
\hline PG & 1.000153 & 1.011014 & 1 & & \\
\hline GDP & 1.093666 & 1.008573 & 1.008911 & 1 & \\
\hline ADR & 1.056345 & 1.076225 & 4.623194 & 1.018669 & 1 \\
\hline
\end{tabular}

The results of variance inflation matrix are presented in Table IV. The rule of thumb is that if the value of VIF equal or lies above 10 then we can conclude that there is a problem of multicollinearity. The results presented in Table IV show that calculated values of VIF for all independent variables are less than 10 indicating no issue multicollinearity.

Long run Panel ARDL results are displayed in Table V. The results of present study show positive and significant impact of misery index on remittance which underpins altruism theory and is also in line with the findings of (Akçay, 2018). It is deducible from the result that if misery of country is high the remittance is also high. As far as the threshold level of misery is concerned we are silent. The variables population growth is significant and possess negative sign. The results postulate that if population of a country is high or household's size is large the inflows of remittance will decrease, which is contradictory to the results of (Niimi et al., 2008). They argued that an increase in population growth will decrease per capita remittances but the total remittance will increase. The negative relationship between remittance and economic growth 
shows that the receipts of remittance will be less dependent on remittance if living in a country where economic conditions are stable and GDP growth is high. The results are similar to the findings of Chami et al. (2005) which conclude that remittance and economic growth are inversely related to each other. They used panel data for 113 countries for over thirty years' time period. Another study by Spatafora (2005) finds that the role of remittance in per capita output growth is negative. They studied 101 developing countries and taken yearly data from 1970 to 2003.

Table V: Long Run and Short Run Panel ARDL Results

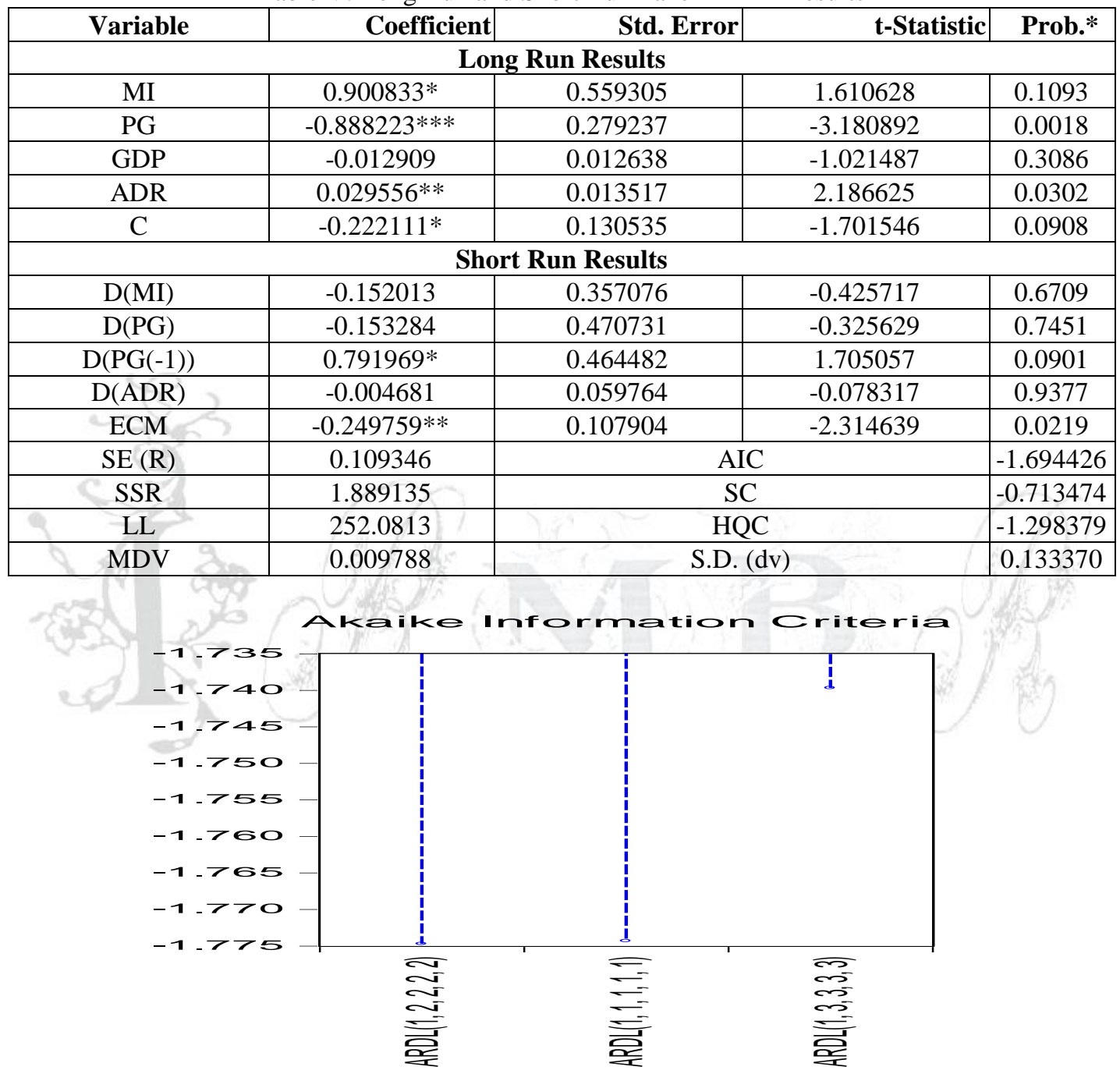

Figure No 1

The coefficient of age dependency ratio showed up with positive sign and statistically significant. This variable is linked with altruism factor as more people are dependent it is likely to increase inflow of remittance. The study by Fonchamnyo (2012) scrutinises economic determinants of remittance inflow and socio-political factors. Unbalanced panel data has been used for 36 countries of Sub Saharan African Region. Unbalanced panel data has been used for 36 countries in Sub Saharan African Region. Random effect approach is used for the analysis and the results show that altruism has an indispensable role in sending money. Furthermore, age dependency ratio and per capita income discrepancy between host and home country are positive and statistically significant. 
On the other hand a contradictory study by Jackman (2013) attempts to build a link between remittance and age dependency ratio using panel data of 93 countries. The author finds that remittance and age dependency ratio is significant and negatively associated with remittance. The short run results show that all the variables are statistically insignificant. The justification of the outcome of the short run result comes from the sending behavior of remittance which is a long term phenomena as it takes some time to earn sufficient income that can be sent back to the native country. The ECM value is significant and negative which indicates that the speed of the model towards equilibrium is almost four years.

\section{Conclusion and Policy Implications}

The objective of the present study was to examine the impact of misery index on remittance. The countries taken into account are India, Pakistan, China, Malaysia, Sri Lanka and Thailand over the period of 19802016. The estimation technique used for the analysis was panel ARDL. The results of panel ARDL show that variable of interest that is misery index has a positive and significant impact on remittance in the long run. Therefore, the results support the altruism theory in remittance sending behavior. Moreover, all the other control variables are significant in the long run. Nevertheless, in short run all the variables are insignificant which is shocking for the South Asian countries. The results confirm that the postulated model converges to the equilibrium in four years.

The study concluded that if macroeconomic variables like unemployment and inflation rate are high then the level of remittance inflow increases (see for instance Akçay, 2018). Altruism is a psychological theory that states that people do have concern for the wellbeing of others. The conclusion of our study is pertinent to the notion of the altruism theory. Remittance and unstable macroeconomic condition are directly proportional to each other in Asian developing countries. However, the government may scrutinize and determine the threshold level of instability otherwise the inflow of remittance might decrease.

\section{References}

Akçay, S. (2018). Remittances and misery index in Turkey: Is there a link? Applied Economics Letters, 25 (13), 895-899.

Awdeh, A. (2018). The socio-economic effects of remittances in the labour-exporting MENA countries. International Journal of Emerging Markets, 13(1), 249-266.

Campbell, T. (2003). Determinants of foreign inflows from current transfers into Barbados. Savings and Development, 27(2), 119-134.

Chami, R., Fullenkamp, C., \& Jahjah, S. (2005). Are immigrant remittance flows a source of capital for development?. IMF Staff Papers, 52(1), 55-81.

Diego, E. V., \& Ruby, K. (2014). Remittances, international reserves, and exchange rate regimes in 9 Latin American Countries. Applied Econometrics and International Development, 14(2), 98-116.

Fonchamnyo, D. C. (2012). The altruistic motive of remittances: A panel data analysis of economies in Sub Saharan Africa. International Journal of Economics and Finance Archives, 4(10), 192-200.

Hai, T. H., \& Doan T. (2017). Remittance and inflation - An empirical study for Vietnam. Asian Journal of Economic Modelling, 5(2), 186-193.

Heilmann, C. (2006). Remittances and the migration-development nexus: Challenges for the sustainable governance of migration. Ecological Economics, 59(2), 231-236.

Jackman, M. (2013). Macroeconomic determinants of remittance volatility: An empirical test. International Migration, 51(1), 36-52.

Lin, H. H. (2011). Determinants of remittances: Evidence from Tonga (IMF Working Paper No. 11/18). Retrieved from: https://papers.ssrn.com/sol3/papers.cfm?abstract id=1755435

Narayan, P., Mishra, S., \& Narayan, S. (2011). Do market capitalization and stocks traded converge? New global evidence. Journal of Banking \& Finance, 35(10), 2771-2781.

Niimi, Y., Ozden, C., Schiff, M. (2008). Remittances and the brain drain: Skilled migrants do remit less (Annals of Economics and Statistics, No. 97/98). Retrieved from: 
https://www.jstor.org/stable/pdf/41219112.pdf?refreqid=excelsior\%3Abe6e9f3c496fa55b569b34457dc $6352 \mathrm{e}$

Pesaran, M. H., Shin, Y., \& Simth, R. G. (2001). Bounds testing approaches to the analysis of level relationships. Journal of Applied Econometrics, 16(1), 289-326.

Spatafora, N. (2005). Remittances: Transaction costs, determinants, and informal flows (World Bank Policy Research Working Paper No. 3704). Retrieved from World Bank website: http://documents1.worldbank.org/curated/en/610101468141260179/pdf/wps3704.pdf

Walsh, B. M. (1974). Expectations, information and human migration: Specifying an econometric model of Irish migration to Britain. Journal of Regional Science, 14(1), 107-120.

\section{Appendix}

Table A: Description of the Variables

\begin{tabular}{|l|l|}
\hline Variables & \multicolumn{1}{|c|}{ Description } \\
\hline LOGREM & $\begin{array}{l}\text { Personal remittance (\% of GDP) which comprises personal transfers and } \\
\text { compensation of employees. Personal remittance has a more comprehensive definition } \\
\text { as of worker remittance (see World Development Indicator). }\end{array}$ \\
\hline ADR & Age dependency ratio (\% of working-age population). \\
\hline MI & $\begin{array}{l}\text { Misery index which is the sum of unemployment (\% total labor force) and inflation } \\
\text { consumer price (annual \%). }\end{array}$ \\
\hline GGDP & GDP growth (annual \%). \\
\hline PG & Population growth annual change \% \\
\hline
\end{tabular}

